\title{
FAKE NEWS AS A WEAPON OF PERSUASION
}

\author{
PIER PAOLO PEDRINI ${ }^{1}$ \\ ${ }^{1}$ University of Lugano, Via Buffi 13, 6900 Lugano, Switzerland. ORCID: https://orcid.org/0000-0002- \\ 0060-976X, Email: ppedrini@swissonline.ch
}

ABSTRACT: Our study is qualitative research. It is a content analysis of more than 2,500 European and American posters of war propaganda identifying modern principles of persuasion and forms of discourse. The analysis of the themes demonstrates that the techniques used one hundred years ago to convince civilians to enlist had enormous potential for development to such a degree that they were adopted by modern political and commercial persuasion. Therefore, we can consider the propagandists of the Great War as modern spin doctors. The idea evolved after reading Propaganda (1928) by Edward Bernays, the nephew of Sigmund Freud. This is an astonishing book; it provides illuminating interpretations both for understanding of war propaganda - not just for the Great War - and for the commercial discourse of which Bernays became a promoting agent.

During the Great War the propagandists used emotional and rational stratagems to convince volunteers to leave to the front. Among these, the fake news played an important role in the production of the posters that served to motivate and galvanize people to defend the ideals of the war. It was an organized disinformation action because, especially for American people, the war was very far in kilometres and in interest. Fake news has two different factors: wrong or unreasonable argumentations and false information used as premises. The success of the posters was that of moulding the agenda-setting and the opinion of citizens in order to increase the enlistment to defend the identity of the nation.

KEYWORDS: propaganda, persuasion, manipulation, fake news 


\section{INTRODUCTION}

In Falsehood in Wartime (1928) Lord Ponsonby denounces the manipulative role played by the newspapers and the posters during the Great War. He lists and discusses the stratagems used by Allied Forces to sustain the war effort:

1. we do not want war, we have to defend;

2. only the enemy is responsible;

3. anyone who criticizes is a traitor;

4. the enemy is using weapons which are forbidden;

5. the enemy commits atrocities willfully, ours are involuntary errors;

6. we have few casualties, the enemy has suffered enormously;

7. war has a sacred peculiarity;

8. demonize/dehumanise the enemy;

9. the war is for a noble cause.

We can consider these statements as 'fake news' because we can read them in the description of every modern war. As a conclusion, Lord Ponsonby (1928: 3) declare that 'when war is declared, truth is the first casualty'.

Actually president Woodrow Wilson justified armed intervention as the defence of American values (democracy, liberty, justice and family) ${ }^{1}$, emphasizing the fact that only the enemy is responsible. The same did the Allies and also German. For this reason, the war was only a preventive measure.

This strategy was the persuasive tactic chosen by the government in order to have the consensus and the support for its decisions. The strategy consisted in spreading insecurity through the diffusion of messages which they guided in two complementary directions: the condemnation of the threats and crimes committed by the enemy (Ponsonby Nr 5) and its consequent demonization (Ponsonby Nr 8). In spreading this fear, the government had formed the paradigm of dread, which facilitated acceptance on the part of its public of messages containing indications of how to confront the threat. What the enemy did elsewhere, could happen to you in your country, especially if you don't do anything to repel him.

Therefore, the most important verb is 'to defend' (Ponsonby Nr 1): your home, your country and the defenceless part of the society. As we said, the same did the enemy. Everybody has to defend, but nobody attacks (Ponsonby Nr 2).

Years later, Hitler ordered 'false-flag' attacks against german targets; in this way he could sustain that his next assault would be a defensive action.

We find interesting to outline that during the Great War the politician who worried about the war was called 'Minister of the War', but after the war, he became the 'Minister of the Defence'. An essential change of the perspective that ennobles this function.

According to Kahneman (2012) today, the defence of the status quo guide our decisions, and it is a powerful, persuasive principle. Remembering the inhumanity of the enemy towards the most vulnerable members of society and its private affection for them, was consequently a useful expedient for mass persuasion.

Reflecting on the general situation of today N. Chomsky (1988:207) wrote: 'A con-

\footnotetext{
${ }^{1}$ According to Cialdini (2006) this belong to the principle of scarcity.
} 
fused and frightened public, used to believing that demons (...) are ready to take away everything they possess, are predisposed to fanatic nationalism'.

Beyond the trust they wished to infuse into the target, the propagandists hoped to obtain a consensus by means of the expression of a value, which could also have taken place by representing its opposite, and of associations shared by the culture of the spectator and his identity.

To communicate effectively, therefore, it was absolutely necessary a solid base of values, beliefs and familiar accords which could guarantee shared areas of meaning and predictability. Consequently, with reference to W. Lippmann's 'consensus factory' (Lippmann 2010), culture is a filter through which messages are chosen.

The source of the message is the government and people trust in it. Denouncing a problem and suggesting the solution to liberate the listener from the task of finding one and guiding him along desired channels of interpretation is a manipulative strategy (Chomsky 1988).

We can find this stratagem in the writings and discourses of politicians and religious leaders from the first centuries a.d. until our days.

\section{METHODOLOGY OF RESEARCH}

We exemplify the results of our qualitative research (Pedrini 2017) by presenting the persuasive principles (Ariely 2008, Cialdini 2006, 2016, and Kahneman 2012) which have emerged from the examination of more than 2,500 posters of the American and British propaganda, with a few examples from other countries. To collect the material, we have visited the Canadian War Museum (Ottawa), the Imperial War Museum (London), the Museum of the City of New York (New York) and the Library of Congress (Washington).

The posters have been subdivided and discussed on the basis of the various techniques and distinctive themes of persuasion, of the theory of decision-making and of social psychology. Thus we have found out a persuasive strategy of the posters.

\section{RESULTS OF RESEARCH}

We firmly think that the use of fake news has been a convincing argumentation, a robust method of persuasion. We have found out that the more significant part of the posters was depicted with the same social techniques that are used today in the construction of advertising messages and political discourses. In other words, we can say that today we sell products with the same techniques used by the propagandists to sell the Great War. Communication techniques are scientifically the same, meekly obeying the universal laws of persuasion, with no difference whatsoever. War propaganda used a simple and accessible tool: billboards which once were the real mass media. However popular sub-consciousness has been subjected to tools namely satire, parody, humour and fear - therefore, emotion and rationality - to line-up the parties (male for drafting, women on the homefront and investors focused on bonds) for the required reaction. The thorny issue of communication ethics arose even when TV didn't still 
exist.

\section{DISCUSSION}

During the Great War the government of all combatant nations presented public arguments for patriotic behaviour to legitimate the war with the medium of billboards. At a general level, all nations shared a common strategy in the use of posters because all the government recognized that they communicate essential information rapidly and efficiently!

Billboards were the voice of the government will and therefore represented the authority ${ }^{2}$, also known with the name 'experts euristic' (Kahneman 2012).

According to Aristotle (1999: 43) sources facilitating the persuasiveness of messages are highly regarded, worthy of confidence, authoritative, believable, expert (competent, professionally successful), honest and trustworthy.

Through the use of authoritative figures, Propaganda illustrates behavioural models to adopt and suggests words to employ when thinking of and to describe the enemy or interpreting its actions. Authority is also confirmed by means of phrases taken from speeches by influential political figures or literary quotations. A billboard repeats Shakespeare' verse of Macbeth: 'Stand not upon the order of your going. However, go at once. Enlist now'.

With a considerable advance on the modern advertising theory, every nation agreed that images were stronger than words and that it was the most crucial medium for the construction of a pictorial rhetoric of national identities.

Both British and American soldiers were idealized and described as courageous, cordial, good-looking ${ }^{3}$, happy to serve their country and to celebrate the successes obtained in the name of civilization.

The use of pictures of good, happy soldiers is a way of re-enforcing national group identity and of tranquillizing parents who stay at home waiting for news coming from the front (Ponsonby $\mathrm{Nr} 6$ ). Nevertheless, it was also a way to motivate people to leave to the front.

For this winning goal, propagandists suggested a lot of personalized promises and benefits like to learn a trade, to have an education, to earn, to have success, to travel around the world for free (the text of two magnificent and eloquent billboards say: 'See the World. And you get paid for it'; 'You cannot be a Man of the World unless you see the World. Join the Army and travel round the World for nothing'), and to stir up admiration in your country.

The text of billboards incited the pride telling that you will be 'Honored and Respected by all. Enlist for the Infantry - or in one of the other 12 branches'.

But the main 'reason why' (Reeves 1960) is that leaving is a significant value and in-

\footnotetext{
${ }^{2}$ According to Cialdini (2006) authority is also a principle of persuasion.

${ }^{3}$ This observation connects us to the words of Aristotle (1999: 55): 'The soul is like the form of the body'.

It goes without saying that, for Hitler (2000: 41), the Jewish physiognomy was rather far from his aesthetic tastes to the point that he complained because 'thousands of girls have fallen in love with repulsive Jewish bastards with crooked legs'.
} 
vestment for your future, 'A wonderful Opportunity for you', as a billboard concludes. 'Opportunity' is a very diffused word. Theirs was the struggle of good against bad. It was a 'mission of peace', as today we are used to say.

Combatting became a mission of civilization (Ponsonby $\mathrm{Nr}$ 9) to 'make the world safe', or to 'keep the world safe for Democracy', or to 'make the world a decent place to live in' as different slogans of the allies' billboards say.

The Americans used the weapon of fear ${ }^{4}$ in many posters to emphasize the difference between their civil way of fighting and the barbarous deeds of the enemy and to motivate everyone to join their mission of civilization and the diffusion of democracy.

As the text of an American billboard summarizes, the war is needed 'For the safety of Womanhood, for the Protection of Childhood, for the Honor of Manhood and for Liberty throughout the World. Help till it hurts'.

The real war was between two different vision of the problem: the german 'Kultur' (a word that is always written in german), that commit every kind of atrocity (as a British poster report: 'It's more serious than you think. The barbarian is almost at your gates. He violates, plunders, murders. Don't let him get a footing on British soil') and the 'humanity' of the Allies, that first of all protect the undefended, the weakest part of the society, help them to run away and want to stop the german cruelty and to repel its invasion (Ponsonby Nr 5).

As Pratkanis and Aronson recall (1992: 177) in 1932, Hitler incited his followers with words meant to alarm them with the strategy of fear:

There is confusion in the street. The Universities are full of rebellious students in revolt. The communists are trying to destroy the country. Russia is threatening us with its power, and the republic is in danger. Yes, in danger from within and from without. We need law and order! Without these, a country cannot survive.

The stories of atrocities committed by enemies are an essential element of every war propaganda, even of the modern one. There is a broad distribution of narratives describing German as barbaric and militaristic; his leader as a demoniac despot (because it has always been more natural to hate a person than people) and his army a blood-thirsty rapist and a direct threat to the civil ideals.

All these billboards would have successfully played on the emotions of the time. All these billboards would have played an essential role in defining identity ${ }^{5}$. Furthermore, having an obstacle by which to measure the values of civil people.

Therefore it is essential to have an enemy, and if he does not exist, governments must create him in order to perceive themselves as a close and reliable group! ${ }^{6}$

The slogan of an American billboard says: 'Are you 100\% American? Prove it! Buy U.S. Government Bonds'. Now you have to demonstrate your attachment to the nation and the government tell you how. Even a British billboard, titled 'The real Irish spirit', shows a civilian stopping a soldier and telling him 'I'll go too!' with enthusiasm. The

\footnotetext{
${ }^{4}$ According to the principles of Cialdini (2006), we can see this as the principle of scarcity.

${ }^{5}$ According to Cialdini (2016), identity is a principle of persuasion.

${ }^{6}$ According to Cialdini (2006), this belong to the principle of social proof.
} 
text of another one tells that 'Britons have never failed in their duty. And never will. Enlist for the defence of your homes and country'.

Mainly Goebbels and Hitler regarded the Program of Information of the American Government during the Great War as a model from which they took the inspiration for building their own information industry.

They exploited this expedience to build a solid German identity representing a worrisome Jewish and communist threat, and emphasizing a common Aryan heritage, they justified the cruelties to be perpetrated against the enemy.

The enlistment is a natural action if you love your fatherland and you recognize you as an enviable patriot. Billboards showed the correct and desired attitude and behaviour.

Even if you didn't leave to the front and you decided to stay home, it was by looking at posters that citizens learned to see themselves as members of the Home Front. Women took posters as evidence that their contribution to the war effort was essential. They were proud to be the second line of the army, but without weapons. Many billboards praised them for the work, and this was indeed a new attitude towards the women, exploiting the principle of reciprocity: 'On her their lives (of the soldiers) depend', 'These women are doing their bit. Learn to make munition', 'The spirit of women-power', 'The kitchen is the key to victory', 'She is doing her part to win the war', etc.

The Home Front is trained to link its individual strength to the national interest. Women are valued, and their patriotic fervour is aroused: 'your work is a form of military service': there are regulations to respect and orders to follow: enlistment is mandatory!

Women are also urged to the persuasive goal of convincing men to enlist. Posters reach out to male viewers through the gendered rhetoric of shame with the clear message: enlist now, before you suffer the shame of being dragged to the recruiting office by a more patriotic female relation.

Without the consent and material support of the Home Front, combatant nations would not have been able to sustain the enormous losses of the war.

But a group has not the same psychological characteristics as an individual and is therefore motivated by impulses, habits and emotions.

Some years later after the end of the war Edward Bernays (1928: 72) perceived by intuition that the public is like 'a flock that needs to be guided' and that this renders people 'well disposed towards the ruling class'. Therefore, it is necessary to tell them what to think because, by themselves, they are not capable of doing so rationally.

As Thaler and Sunstein (2008) demonstrate, this principle is still valid, and even today, it is necessary to give people some datum-point to orient the compass of their attitude and behaviour.

Incidentally, we should mention that even Hitler, too, many years later was convinced that his action against 'the abuses and vile practices that the Jews committed every day' against the German public was a 'duty of civilization' to conserve 'Aryan man' (2000: 96).

Precisely this takes still place when the army of a nation with a lifestyle comparable to ours decides to fight against one with different conceptions of civility, freedom and 
justice: for example, the wars in Korea (1950), Vietnam (1965), Kuwait and Iraq (1991), Libya and Syria, etc.

We could recall that in 2003 the English Prime Minister T. Blair succeeded in manufacturing an accusation against $\mathrm{S}$. Hussein, which accused him of being in possession of weapons of mass destruction (Ponsonby Nr 4).

Even during the Great War, the opposing parties swapped the reciprocal accuse of using the prohibited gas. As we said above, the propaganda follows a manipulative strategy in denouncing Germany as the cause of all the problems and in suggesting the enlistment as the unique solution.

The definition of the enemy has arrived at by means of the creation of stereotypes or heuristic of representativeness (Kahneman 2012), a technique whose purpose is to arouse public prejudice, labelling the other as individuals that people fear, hate and avoid.

It is one of the primary mechanisms by which reality becomes finally easy to confront: it is a mental short cut, useful for rapid recognition, which seeks the help of generalization and therefore of stereotypes. Actually, the fact that one event seems more typical than another does not make it more probable.

The creation of stereotypes proved to be the fundament of every propaganda effort whose ultimate goal was that of generating the perception that our actions were ethical, whereas those of the enemy were not.

The creation of stereotypes is also the essence of every modern advertising campaign through which designers enhance a characteristic of a product as a plus, so that in the minds of consumers it becomes an essential point of reference and in this way our analysis of a product reduces itself to a quick confirmation of stereotypes with which it has been inculcated.

All of this closely resembles the primacy effect (Kahneman 2012) or the tendency of first impressions to assume a greater significance and to provide a pattern according to which successive information is interpreted. Thus, our perception of events always depends on what we have in our minds (Ariely 2008).

George Creel, the founder and chief of the Committee of Public Information (19171919) - the laboratory of modern propaganda formed by intellectuals, war ministers, journalists and advertisers - wrote (2012: 23) that during the Great War propaganda was 'the world greatest adventure in advertising (...) a vast enterprise in salesmanship'.

In fact, both reveal problems and offer solutions; they are used to obtain approval and to create expectations with the goal to control the actions of influencing attitudes. To join this aim, they both often use the strategy of distraction, thank to which facts are presented selectively, any information is omitted, and you can use euphemism if that helps you to create a persuasive message and 'to convince of the goodness of an ideal' (Hitler 2000: 36).

Propaganda and advertising also insist on details that evoke emotional responses. For the modern time Chomsky (2002: 47) consider that propaganda is an essential component in the entire political process and writes that 'Democratic systems must control what people do and think because in a democracy the politically active segments of the population, the most educated and privileged, have to be kept under 
control'.

Posters referring to religion (Ponsonby Nr 7) were also exhibited, and even Woodrow Wilson's Declaration of War concludes with the words 'God helping her, she can do no other'.

An Irish billboard shows a farmer who has a vision of St. Patrick during his work and the slogan ask: 'Can you longer resist the Call?', where the term 'Call' is written with capital letter, and so you can't distinguish if the author of the question is the propagandist (or the government) or St. Patrick himself, who reflect the divine Will. In this way, you confuse the origin of the war, and you make an excellent appeal to the numerous believers.

The message of this kind of billboards had a didactic function in that it suggested appropriate behaviour to the public and indicated what the nation, but overall the government, expected of him. ${ }^{7}$ For this reason, soldiers were called and portrayed as crusaders fighting against evil and contributing to the diffusion of democracy and American values in the world (Creel 2012).

As Morelli (2010: 119) wrote, the Allied cause took on a sacred character referred by President T. Woodrow Wilson in a second address to gain public approval' ${ }^{8}$ ' This was a war for democracy, a war to finish all wars, a war to protect liberalism, a war to free barbarous Europe, a crusade'.

By the way, in September 1919 only, he admitted that 'We all know that this was a commercial war'. This topic also appeared in French and British propaganda. The infidel was the other, the unknown, and therefore the hun, which was a further motive to combat him. Enemy is the devil, a monster different from us in everything (even physically) and in his way of life. Many slogans suggest you 'Halt the Hun' or 'Beat back the Hun', denouncing that 'Germans are Barbarian' and therefore you have to 'Destroy this mad Brute'.

Enemy is someone who is different from us, he has different habits from ours (he is overall a Hun), and his diversity means a real threat to our civil life.

The British humour coined the neologism 'Germ-Hun' joking on the alliteration with 'German'. To convince the public to defend the borders and freedom of the homeland, neutral Switzerland also diffused by postcards, and not by billboards, a national poem which last verse was 'Mit uns Gott' (God is with us). Similarly, together with the swastika, years later the Nazi logo likewise expressed 'Gott mit uns'.

Regarding our times, Bush invaded Iraq using the invocation 'God bless America', while the ISIS movement is presented as a divine mission to be fulfilled in the name of a prophecy. We need only think of the ample use of fear on the part of ISIS, maintaining that everyone is free to kill infidels 'until you eliminate from the world human life which does not respect Allah' (Erelle 2015: 88).

Returning to the Great War we have to say that also the words used to form the slogans are often borrowed from the religion: 'They crucify American Manhood'; 'Your sons are fighting for you. Sacrifice to help them win. Buy Liberty Bonds'; even children

\footnotetext{
${ }^{7}$ According to Cialdini (2006), this belong to the principle of social proof.

${ }^{8}$ According to Cialdini (2006) this belong to the principle of liking.
} 
are invited to make 'An Heroic Sacrifice' and to avoid eating cookies and ice-creams in order to save sugar.

The success of the persuasive strategy used to create billboards is evident: at the outbreak of the war the British Army numbered of 450,000 men, but in six months, between August 1914 and January 1915, 30,000 people were leaving for the front every day. At the end of the year 1915 they were 5 million strong, half of these enlisted in only 16 months when the enlistment was not obligatory yet.

On the American side, the army numbered no more than 200,000 men at first, but in the end, after 20 months of the war, it was composed of more than 4 million people. The 'Liberty Loan' campaign also helped involve ordinary citizens in the war effort. Parents are willing to grasp onto anything that can give them an ounce of hope and make them feel as if they are contributing as much as they can to bringing their son home safe. It makes them feel like they are at least a tiny bit in control.

The final aim is to guilt people into buying loans, and the success of the outcome is stupefying: nearly one-third of the entire American population purchased at least 1 'Liberty Loan' or 'Government Bond' or, in Australia, 'Peace Bond', in favour of the army. In this way, two-thirds of the total cost of the war has been covered.

To encourage people to giving money to the army, the propagandists used the ancient persuasive principle of reciprocity. Many posters show soldiers looking for visual contact with the viewer and telling 'We are fighting for you' or 'We are on the top for you' with the question 'What are you doing for us?' that remains implied.

Some billboards take their inspiration from the fear strategy and warn: 'German Slavery or Liberty Bonds'. Other billboards show a happy and satisfied soldier with a warm coffee on the one hand and a sandwich in the other hand. An off-screen voice comments: 'If you only knew! - how much joy your dollars bring “Over there” you'd give and give and give!!!'.

The 'War Saving Certificates' paid a good interest on the loan, and therefore it was desirable to buy them because, as the slogan of a billboard remember: 'Old age must come'. Sure life insurance.

According to Robin Dickinson, after the war, the psychological methods are utilized to shift the critical function of the consumer from the product to himself. The advertiser has to awaken feelings of guilt and fear; insist on the fact that respectable people do not live as he does. The reference to fear becomes fundamental, and the mission is to 'make him aware of the size of the pores on his nose or of his bad breath' (Dickinson 1937: 73). In 1937 the director of an advertising agency in New York urged his colleagues to put 'A bit of fear into their advertising... fear of being shabby women, of being unsuccessful men' (1937: 84).

The fundamental principles used in the recent past are a useful and instructive instrument to understand modern persuasion and time. 


\section{CONCLUSIONS}

The content of the Ponsonby' list exist, with different priorities, in the description of every modern conflict (Morelli 2010), and continues to be regarded as real. Chomsky describes it (2002: 208) as 'the fundamental doctrine according to which the State is of itself good and guided by the noblest intentions, only trying to defend itself and does not figure as an active subject in world affairs but simply reacts to the crimes of others, at times imprudently because of its own naivety, the complexity of history or its incapacity to understand the evilness of the enemy'.

In re-reading the Great War posters according to the principles of modern persuasion, we have provided an interpretation of them and a useful organization in defining the strategy of the propagandists. We have implicitly demonstrated how these modern principles were anticipated by them one hundred years ago to obtain public consensus, modifying and controlling public opinion.

In particular, at first, the goal is to cultivate a positive tie, and therefore reciprocity and liking are suitable. Then, people want to see if it is worth it, and the priority becomes the reduction of uncertainty with authority and social proof. Lastly, with the principle of scarcity and consistency, a reason for action is stated.

The nucleus of the strategy to manipulate the enemy has always been the war of information ${ }^{9}$ to gain an internal consensus and conquer enemy territory without fighting. The success of the subjects and the effectiveness of the persuasive techniques used to create poster campaigns which were carried out to induce agreement and modify attitudes was incontestable.

Understanding what propaganda is and the mechanism that it uses is an essential task for understanding modern time. Today we can find the same principles of persuasion in political discourses and commercial advertising.

Immediately after the Great War, psychological methods were increasingly employed by advertisers to shift the critical functions of consumers from the product to themselves. What they wanted was to awaken sentiments of guilt and fear by insisting on the fact that respectable people did not live as they did.

Products became the solution to psychological complexes because they lent personality and status to purchasers, allowing them to feel at peace with themselves and giving them the illusion of finding aspects of themselves in the objects they acquired. Products mirrored their history.

We must also take into consideration the discourse of politicians, insurance agents and doctors who show their interlocutors potential problems while offering in advance plans of action, contracts or products as solutions. Marketing strategists know that they attract more customers if they stress risk and fear, exploiting this by selling products which promise security and personal safety, thus rendering the uncertainty of the future less problematic.

This is a market which is growing exponentially and which is ignored neither by

\footnotetext{
${ }^{9}$ In 1917 Lord Beaverbrook, owner of the Daily Express, commented that propaganda was the popular weapon of diplomacy in which 'the munitions of the mind became not less vital for victory than fleets or armies' (Welch 2013: 86).
} 
political posters during electoral campaigns, in which it functions as an important resource for winning a consensus, nor by the mass media which offer a view of the world which is presented as very dangerous and threatening in order to have more listeners and viewers.

FUNDING: This research received no external funding.

CONFLICTS OF INTEREST: The author declares no conflict of interest.

\section{REFERENCES}

Ariely, Dan. 2008. Predictably Irrational. New York: Harper Collins.

Aristotle. 1999. Poetica. Milano: Mondadori.

Bernays, Edward. 2007 [1928]. Propaganda. Paris: La Découverte.

Chomsky, Noam. 2002 [1987]. Linguaggio e libertà. Milano: MarcoTropea.

Chomsky, Noam and Edward S. Herman. 1988. Manufacturing Consent: The Political Economy of the Mass Media. New York: Pantheon.

Cialdini, Robert. 2006. Influence: The Psychology of Persuasion (1984). New York: Harper Business.

Cialdini, Robert. 2016. Pre-suasion. New York: Simon\&Schuster.

Creel, George. 2012 [1920]. How we advertised America. Lexington: Forgotten Books.

Dickinson, Robin E. 1937. Freshen Up Your Product. New York: John Walter Thompson Company.

Ewen, Stuart. 1988. I padroni della coscienza (1976). Bari: De Donato.

Erelle, Anna. 2015. Nella testa di una jihadista: un'inchiesta shock sui meccanismi di reclutamento dello stato islamico. Milano: Tre60.

Hitler, Adolf. 2000 [1939]. Mein Kampf. Roma: Riforma dello Stato.

Kahneman, Daniel. 2012. Thinking, Fast and Slow (2011). London: Penguin Books.

Lee, McClung A. and Elizabeth Briant Lee. 1972 [1939]. The Fine Art of Propaganda. New York: Octagon Books.

Lippmann, Walter. 2010 [1922]. Public Opinion. Sioux Falls, SD: Greenbook.

Morelli, Anne. 2010. Principes élémentaires de propagande de guerre: utilisables en cas de guerre froide, chaude où tiède. Bruxelles: Aden.

Pedrini, Pier Paolo. 2017. Propaganda, Persuasion and the Great War. London \& NY: Routledge.

Ponsonby, Arthur. 1928. Falsehood in War-Time. London: Garland Publishing Company.

Pratkanis, Anthony R. and Elliott Aronson. 1992. Age of Propaganda: The Everyday Use and Abuse of Persuasion. New York: W. H. Freeman \& Co.

Rawls, Walton H. 1988. Wake Up America! New York: Abbeville Press Publishers.

Reeves, Rosser. 1960 [1940]. Reality in advertising. New York: Knopf.

Sternthal, Brian and Samuel C. Craig. 1974. "Fear Appeals: Revisited and Revised." Journal of Consumer Research 1(3): 22-34. DOI: https://doi.org/10.1086/208597

Thaler, Richard R. and Cass R. Sunstein. 2008. Nudge: Improving Decisions About Health, 
Wealth and Happiness. New Haven: Yale University Press. Welch, David. 2013. Propaganda: Power and Persuasion. Trento: Printer Trento. Zizek, Slavoj. 2009 [2006]. Leggere Lacan. Torino: Bollati Boringhieri.

\section{BIOGRAPHICAL NOTE}

Pier Paolo Pedrini is guest lecturer at the University of Lugano, Switzerland.

OPEN ACCESS: This article is distributed under the terms of the Creative Commons Attribution Non-commercial License (CC BY-NC 4.0) which permits any noncommercial use, and reproduction in any medium, provided the original author(s) and source are credited.

ARTICLE HISTORY: Received 2019-01-09 / Accepted 2019-12-03 